\title{
Exploratory Study on Alignment Between IT and Business Strategies
}

\author{
Wahyuni Reksoatmodjo \\ Faculty of Engineering, Universitas Gadjah Mada, Yogyakarta, Indonesia \\ Jogiyanto Hartono \\ Faculty of Economics \& Business, Universitas Gadjah Mada, Yogyakarta, Indonesia \\ AchmadDjunaedi \\ Faculty of Engineering, Universitas Gadjah Mada, Yogyakarta, Indonesia \\ HargoUtomo \\ Faculty of Economics \& Business, Universitas Gadjah Mada, Yogyakarta, Indonesia
}

\begin{abstract}
Interaction and linkages between business and information technology (IT) strategies remain a primary concern among executives. This study aims to gain an in depth understanding of how companies achieve alignment and the policy framework that underlies the efforts, particularly those that are associated with the most dominant factor that contributes to the establishment of strategic alignment, namely IT infrastructure flexibility. For that purpose, the study explored four companies engaged in the field of oil, electricity, and communication by adopting interpretive case study.

Data were gathered using triangulation methods via field interviews, artifacts, document analysis, as well as direct observation. The textual data were elaborated by an intentional analysis in order to guide the study in exploring the phenomenon. The study identified elements that reflect IT infrastructure flexibilities namely connectivity, compatibility, modularity, IT staff knowledge and skills, and integration. Those elements cover both technical and behavioral dimensions of a company's components that need to be included in the consideration during the planning phase
\end{abstract}

\begin{abstract}
Abstrak: Keselarasan antara strategi bisnis dan strategi teknologi informasi (TI) tetap menjadi perhatian utama para eksekutif. Penelitian ini bertujuan untuk memperoleh pemahaman mendalam tentang bagaimana perusahaan mencapai keselarasan dan kerangka kebijakan yang mendasari upaya, terutama yang berkaitan dengan faktor yang paling dominan yang memberikan kontribusi terhadap terwujudnya keselarasan strategis, yaitu fleksibilitas infrastruktur TI. Untuk tujuan tersebut, penelitian ini meneliti empat perusahaan yang bergerak di bidang minyak, tenaga listrik, dan komunikasi dengan mengadopsi pendekatan studi-kasus interpretatif.

Data dikumpulkan dengan menggunakan metode triangulasi melalui wawancara lapangan, artefak, dokumen analisis, serta pengamatan langsung. Data tekstual dijabarkan dengan mengadopsi pendekatan analisis intensional untuk memandu penelitian dalam mengeksplorasi fenomena keselarasan strategis dalam perusahaan. Studi ini mengidentifikasi unsur- unsur yang mencerminkan fleksibilitas infrastruktur TI yaitu
\end{abstract}

Corresponding authors. E-mail: ibu_yuni@ugm.ac.id 
konektivitas, kompatibilitas, modularitas, pengetahuan dan keterampilan staf TI, dan integrasi. Unsurunsur tersebut memiliki dimensi baik teknis maupun sosial yang perlu dimasukkan dalam pertimbangan selama fase perencanaan strategi perusahaan.

Keywords: compatibility; connectivity; integration; IT infrastructure flexibility; knowledge and skills of IT staff; modularity; strategic alignment 


\section{Introduction}

Strategic alignment of information technology (IT) and business strategy has been the focus of attention by IT executives, and has always been the top concern of IT managers for almost 30 years; in the last seven years it has been either the first or second most important topic (Luftman and BenZvi 2010). Alignment of IT - business strategy (commonly abbreviated to alignment) is the implementation of IT applications correctly, timely, and in harmony with business strategies, goals and company needs (Luftman 2003). Prior studies indicated that requirements for alignment are a challenge because of the many perspectives and the requirements that have emerged, depending on the background and purpose of each research.

Some statements concerning how alignment is achieved are (a) IT functions are developed according to business objectives (Mckaway et al. 2009); (b) business strategies are driven, supported, and enabled by the IT strategies (Broadbent and Weill 1997); (c) consistent business objectives and activities of IT-based companies (Woolfe 1993); and (d) company should give priority to IT projects that lead to conditions that allow contents and IT planning process dimensions to become mutually complementary (Das et al. 1991); and (e) IT is able to contribute to the achievement of company objectives at all levels (Lederer and Mendelow 1989). The importance of alignment has been observed by several authors including Sambamurty and Zmud (1999); Luftman (2000); and Chen and Huang (2010), while the positive effects of alignment on a company's performance was summed up by, among others Tallon et al. (2000); Papp (2001); Cragg et al. (2002); and Butchii and Steyn (2008). Nevertheless, in order to achieve alignment, companies need to pursue a comprehensive and sustained effort (Lederer and Mendelow 1989; Luftman 2003; Chung et al. 2003; and Elhari and Bounabat 2011), and also need to consider the social and intellectual aspects of organization (Reich and Benbassat 2000).

More recent studies indicated a shift toward research themes showing the influence of IT infrastructure flexibility on strategic alignment. To some point, previous studies agreed that IT infrastructure flexibility is a key to success of achieving alignment, as expressed by Weill et al. (2002); Luftman (2003); and Chung et al. (2003); Butchii and Steyn (2008); Chen and Huang (2010); as well as Elhari and Bounabat (2011). The concept of IT infrastructure flexibility derives from a need to have IT infrastructure that are manage to face the rapidity of technology changes (Tallon and Kraemer 2003; Chen and Huang 2010).

Following Duncan (1995), previous studies indicated that IT infrastructure flexibility is determined by four characteristics, namely connectivity, compatibility, modularity of IT infrastructures, and the knowledge and skills of IT staff. By adopting a case study as a research design this current research further investigated IT infrastructure flexibilities and their contribution to the development of alignment. Research by Luftman and Ben-Zvi (2010) concluded that the alignment has persisted as a topic of discussion by top managers as presented in Table 1. 
Table 1. Top ten IT Management Concerns (Luftman and Ben-Zvi 2010)

\begin{tabular}{lccccccc}
\hline \multicolumn{1}{c}{ IT management concerns } & 2009 & $\mathbf{2 0 0 8}$ & $\mathbf{2 0 0 7}$ & $\mathbf{2 0 0 6}$ & $\mathbf{2 0 0 5}$ & $\mathbf{2 0 0 4}$ & $\mathbf{2 0 0 3}$ \\
\hline Business productivity and cost reduction & 1 & 7 & 4 & & & & \\
IT and business alignment & 2 & 1 & 2 & 1 & 1 & 1 & 1 \\
Business agility and speed to market & 3 & 13 & 17 & 11 & 5 & 10 & 10 \\
Business process re-engineering & 4 & 18 & 15 & & & & \\
IT cost reduction & 5 & 7 & 4 & & & & \\
IT reliability and efficiency & 6 & & & & & & \\
IT strategic planning & 7 & 3 & 8 & 4 & 4 & 4 & 2 \\
Revenue-generating IT innovation & 8 & & & & & & \\
Security and privacy & 9 & 8 & 6 & 3 & 2 & 3 & 3 \\
CIO leadership roles & 10 & 16 & 10 & & & & \\
\hline
\end{tabular}

Surveys carried out by Luftman et al. (2005), and Chan and Reich (2007) showed that alignment remains an impor-tant issue over the past two decades. Therefore, it is the duty of researchers to conduct exploration on the alignment as well as a variety of perspectives that can be drawn from the alignment in order to reveal how to build and implement the learning outcomes.

\section{Research Objectives and Benefits of this Research}

The purpose of this study is to develop an in-depth understanding of company policies in their attempt to achieve alignment. Confirmed by the conclusions of previous researchers, it is now clear that the flexibility of IT infrastructure have the strongest influence on the alignment, therefore the effort of this study will be focused on the characteristics of flexible IT infrastructures. Ben- efits that can be learned from this study include,

a) a deep understanding of the phenomenon and a description of how companies developed alignment,

b) lessons-learned can be used as a benchmark for other companies to create alignment, and

c) description of the property of IT infrastructures characteristics can be used as a consideration in a decision making process regarding national policy on IT, therefore the public can also benefit and enjoy the good service of the companies that have adopted alignment concept.

In contrast to the previous studies that question the relationship between the components of the alignment of IT infrastructures flexibility (Duncan 1995; Tallon et al. 2000; Byrd and Turner 2000), this study is focused on: 
a) Alignment between IT strategy and business strategy and the company efforts to achieve the condition.

b) Characteristics of IT infrastructure flexibilities that are believed to enable alignment, and how the company develops the infrastructures.

This study differs from previous studies in that knowledge of why alignment is needed in a company as observed by Tallon et al. (2000); Hussain et al. (2002); Tallon (2009), and Chan and Huang (2010) is not the same as the knowledge of how a company achieves alignment. This study also differs from previous studies based on the fact that in previous studies, the presence or absence of relationship between IT infrastructure flexibility and IT alignment, as observed by Duncan (1995); Tallon et al. (2000)1; Byrd and Turner (2000); and Ness (2005), did not show how flexibilities of IT infrastructures contribute to the success of achieving alignment.

\section{Literature Review}

\section{Alignment Concept}

Information obtained from literature indicated the presence of several concepts of alignment which, according to Knoll and Jarvenpaa (1995), can be classified as having a natural-selection, interactions, or multivariate approach. Of the three categories, Knoll and Jarvenpaa (1995) stated that the multivariate approach is the most complete concept. This approach embraces the concept of equifinality - that there are many different equally effective combinations of organizational variables to achieve alignment. Among the most comprehensive works on the concept of multivariate approach are those of
Critical Success Factor (Rockart 1979), Value Chain Analysis (Porter 1985), and Strategic Alignment Model (Henderson and Venkatraman 1992). The concept of Strategic Alignment Model, or SAM) of Henderson and Venkatraman (1992), has been viewed as the most widely accepted, most widely implemented in practice, and most widely referenced in many studies (e.g. Pant and Hsu 1999; Tallon et al. 2000).

\section{Strategic Alignment Model}

The Strategic Alignment Model (SAM) can be defined as a business-IT management framework to enable successful implementation of business and IT, and their corresponding infrastructures components (Henderson and Venkatraman 1992). The SAM model (illustrated in Figure 1), represents the dynamic alignment between the business strategic context and the IT strategic context and is defined in terms of four fundamental domains of strategic choices that consist of: business strategy, IT strategy, organizational infrastructures and processes, and information technology infrastructures and processes.

Each of the four domains has its own underlying dimensions that consist of three components, yielding in all twelve components that further define business-IT strategic alignment. Each domain can be outlined as follows:

1. Business strategy: involves all choices that position the company in the (global) market. It also defines the way in which the company realizes competitive advantage.

2. IT strategy: involves all choices that position the firm in the (global) IT market.

3. Organizational infrastructures and process: Defined as the choices that determine the internal arrangement of the firm in order to execute the business strategy. 
Figure 1. Strategic Alignment Model (Henderson and Venkatraman 1992)

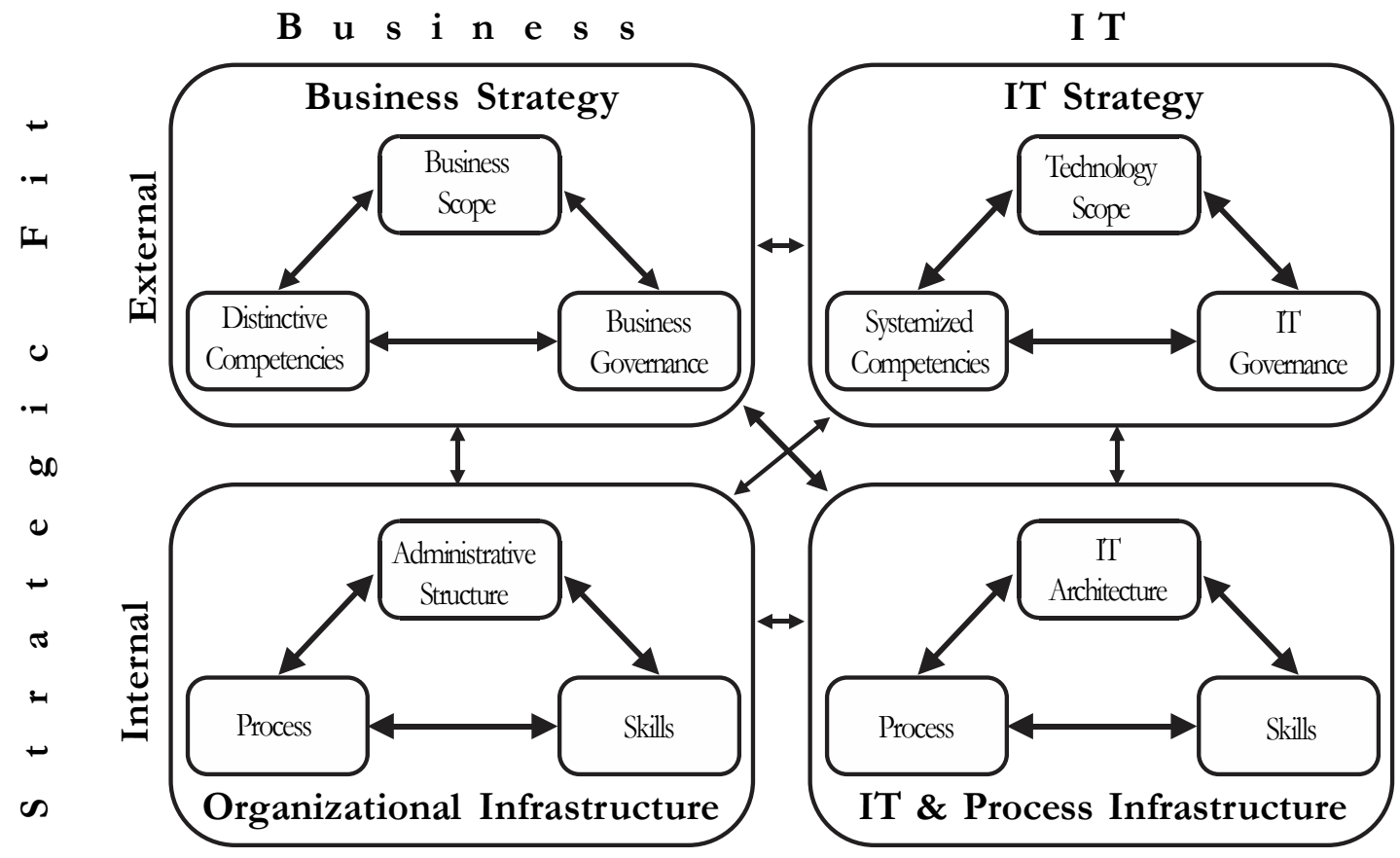

Functional Integration

4. IT infrastructures and process: Defined as the choices that determine the arrangement of IT. It defines how the company executes the IT strategy.

The strategic alignment model identifies two types of integration between Business and IT domains. The first integration is called strategic fit, the second is functional integration. According to Henderson and Venkatraman (1993), the former recognizes the need for any strategy to address both external and internal domains. The external domain is the business arena in which the firm competes and is concerned with decisions such as product-market offering and the distinctive strategy attributes that differentiate the firm from its competitor. In contrast, the internal domain is concerned with choices pertaining to the logic of the administrative structure (functional or divisional or matrix organization) and the specific rationale for the design and redesign of critical business processes (Henderson and Venkatraman 1993).

\section{Perspective of the SAM}

Henderson and Venkatraman (1993), argued that the Business and IT strategy are said to be aligned, when a strategic fit has been realized, and functional integration is reached. Furthermore, alignment requires a balance to be achieved across all four domains. To provide this balance, Henderson and Venkatraman presented four generic alignment perspectives (illustrated in Figure 2).

Each perspective consists of three components, which show an interplay among three key domains shaping a form of a triangle. 
Figure 2. Perspective of Strategic Alignment Model
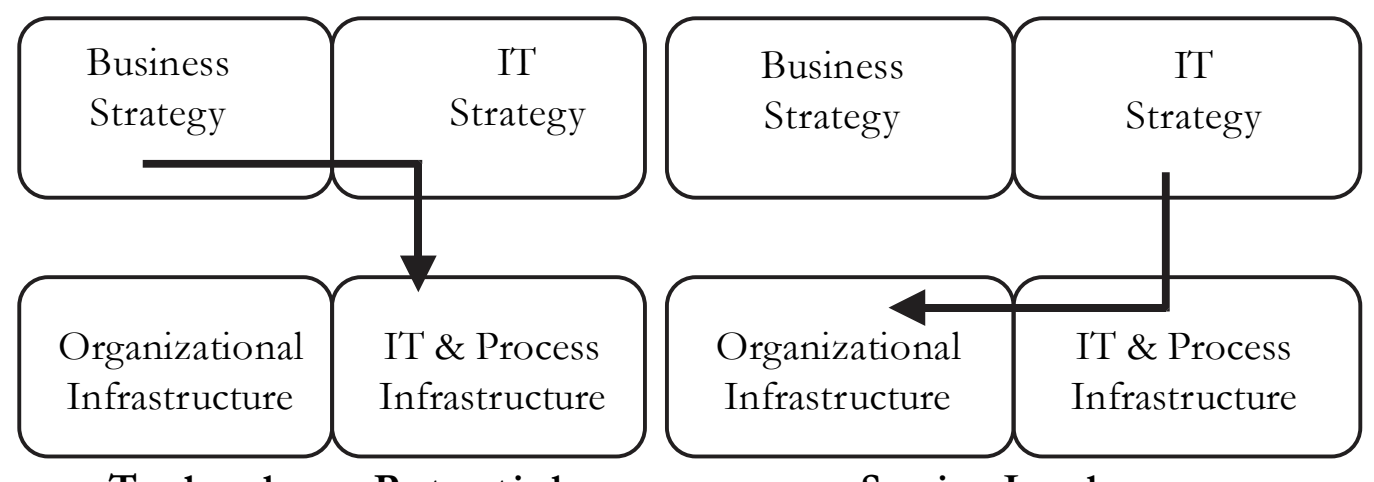

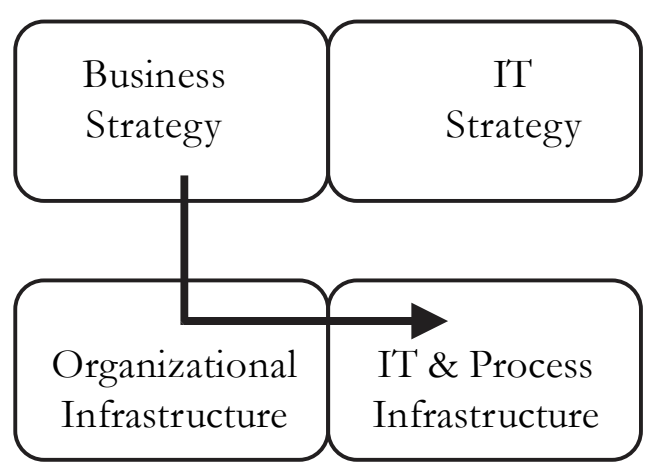

Strategy Execution

The components in the triangle are anchor, pivot, and area of impact. The anchor represents the strongest area of the business. It directs the change that business goes through established alignment perspective. The pivot represents the weak area that is subjects to change through the realignment, whereas impact represents the area that will be directly affected through the changes made in the pivot area through realignment.

Henderson and Venkatraman (1993) described the four alignment perspectives in detail as follows:

Technology potential focuses on assessment of implementing the chosen business strategy through the appropriate IT strategy. This perspective seeks to identify the best possible IT competences. Senior business managers devise the vision whilst the senior IT manage-

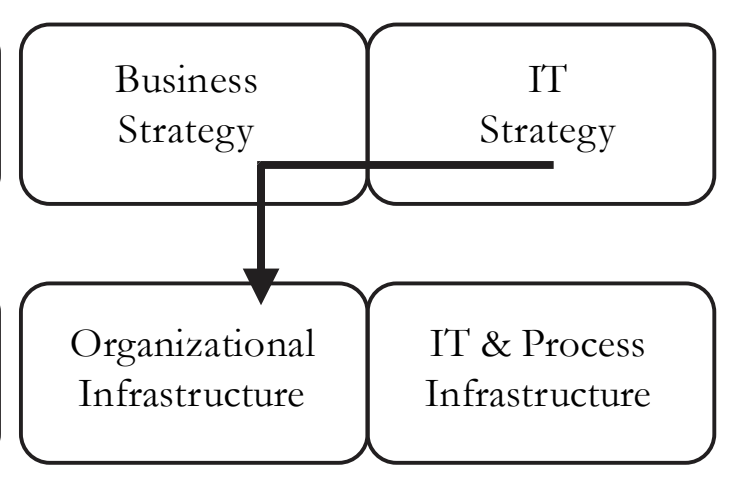

Competitive Potential

ment provides the technical architecture services.

Strategy execution, describes that the business strategy is the sole driver of all domains - adopting the more classical view of IT strategy development. The strategy is formulated by senior business managers and implemented by IT senior management.

Competitive potential is concerned with the exploitation of IT to deliver strategic capabilities. It allows for the adaptation of the business strategy through IT capabilities. Senior business managers devise the vision whilst senior IT managers act as catalysts. And service level concentrated on how to build a world class IT service organization. The last perspective called business strategy is viewed as being indirect and is to stipulate_customer demand only. The role of senior business 
management is to prioritize whilst the senior IT management is one of leadership.

It can be noticed that by adopting one perspective involving cross-dimensional alignment (triangles), both strategic fit and functional integration are included into company's consideration (Henderson and Venkatraman 1992).

\section{Factors that Influence and Inhibit IT-Business Alignment}

Literature on alignment also shows an agreement among researchers that the primary function of IT within the company is no longer as a provider of automation, but rather functions to assist the company's efforts to re-engineer the business process in order to improve work performance and gaining the company competition. To achieve these objectives Sambamurty (2000) suggested that the company should adopt the concept of alignment. Researchers who have the same perception as Sambamurty (2000) are presented in Table 2 .

Previous studies which examined the affecting factors toward alignment condition can be grouped into two categories, the first category examines the most important factors that encouraged alignment (including Knoll and Jarvenpaa 1995; Smith et al. 2007; these are presented in Table 3.

The second category scrutinizes the factors that inhibit alignment. Lack of communication between business and IT managers for instance, can lead business managers to believe in their own ineptness in terms of technical activities, and IT managers assert that it is natural if they do not have notion of business and investment planning. If this happened then the company would suffer from an alignment gap, or differences between the goals of developing applications with the management of IT operations.

Table 2. Summary of the Effect of Alignment of the Company

\section{$\begin{array}{ll}\text { Perception of Alignment in Companies Authors } & \text { Aut }\end{array}$}

Have a greater effect to increased the company's performance work

Have a positive impact on the effectiveness of IT companies and lead to improved performance at work.

Is a better predictor of a company performance, and will be reflected in the company's IT infrastructures.

Affects performance of companies that adopted prospector and analyzer type of strategy.

Is a positive and significant predictor to the potential ability of the company's IT infrastructures, and has a direct impact on overall company performance
Sambamurty (2000); Sabherwal and Chan (2001); Sabherwal and Kirs (1994); Croteau et al. (2001)

Chan and Huff (1993); Tallon et al. (2000)

Chan et al. (1997)

Sabherwal and Chan (2001)

(Xia and King 2002). 
Table 3. Factors Influencing IT-Business Alignment

\begin{tabular}{|c|c|}
\hline Factors that Encourage & Authors \\
\hline IT is supported by Senior executive & Luftman et al. (1999); Kim (2003) \\
\hline Flexibility of IT infrastructures & $\begin{array}{l}\text { Knoll and Jarvenpaa (1995); Duncan (1995); } \\
\text { Luftman (1996); Chan et al. (1997); Byrd et } \\
\text { al. (2000); Papp (1999); Bhatt and Grover } \\
\text { (2005); Kanellis and Paul (2005); Chung et al. } \\
\text { (2003); Gerbauer and Schober (2005); } \\
\text { Overby et al. (2006); Bond et al. (2006); } \\
\text { Chanopas et al. (2006); Smith et al. (2007). }\end{array}$ \\
\hline High quality of information & Kearns and Lederer (2001); Andersen (2001) \\
\hline Historical of IT success & $\begin{array}{l}\text { Van der Zee and De Yong (1999); Reich and } \\
\text { Benbasat (2000) }\end{array}$ \\
\hline Equality between the business with IT & $\begin{array}{l}\text { Jahng and Rammamurty (1998); Luftman and } \\
\text { Brier (1999) }\end{array}$ \\
\hline $\begin{array}{l}\text { Communication/interaction among } \\
\text { business managers with IT }\end{array}$ & $\begin{array}{l}\text { Reich and Benbasat (2000), Van der Zee and } \\
\text { De Yong (1999); Luftman et al. (1999); } \\
\text { Luftman and Brier (1999); Reich and } \\
\text { Benbasat (2000); Kearns and Lederer (2001); } \\
\text { Andersen (2001); Kim (2003); Wagner et al. } \\
\text { (2006) }\end{array}$ \\
\hline $\begin{array}{l}\text { The breadth of the IT opportunities to } \\
\text { participate in business planning }\end{array}$ & Van der Zee and De Yong (1999) \\
\hline \multirow[t]{2}{*}{$\begin{array}{l}\text { Priorities for IT infrastructures projects } \\
\text { company provide channels for open } \\
\text { communication between IT - business } \\
\text { departments }\end{array}$} & Luftman and Brier (1999) \\
\hline & Wagner et al. (2006) \\
\hline $\begin{array}{l}\text { IT understands the business needs } \\
\text { Knowledges accessibility }\end{array}$ & $\begin{array}{l}\text { Reich and Benbasat (2000); Reich and } \\
\text { Benbasat (1996); Andersen (2001); Kim (2003) }\end{array}$ \\
\hline Information System Planning based on IT & Kearns and Lederer (1997) \\
\hline High competence of IT department staff & $\begin{array}{l}\text { Luftman and Brier (1999); Luftman et al. } \\
\text { (1999); Jahng and Rammamurty (1998); } \\
\text { Wagner et al. (2006) }\end{array}$ \\
\hline Effort to periodically reevaluate priorities & Jahng and Rammamurty (1998); Smith et al. (2007). \\
\hline
\end{tabular}


The concept of alignment gap has emerged due to the fact that there are two separate organizational units in any organization, normally the IT department, which is responsible for IT activities and the business department, that has led to the appearance of the gap between IT functions and business activities.

IT function generally refers to the individuals who provide IT services to the com- pany. These individuals are usually highly skilled IT professionals, who have a certain amount of knowledge and experience in software engineering and technical aspects of computer hardware and software systems, and who carry out a variety of tasks to deal with the IT requirements of the firm. A few of the functions of the IT professionals may include design, implementation, and maintenance of the software programs, including

Table 4. Factors that Inhibiting Alignment and Lead to Alignment Gap

Inhibiting Factors

IT department doesn't have staff and leadership that is able to communicate and share knowledge with other departments

IT is too complex and costly to be adopted

IT priorities are not aligned with business priorities

Lack of communication between the IT business department

Limited attention from the department of IT in business strategy development process

No senior executive support for IT

Staff and managers of the company have only a limited perspective toward the corporation

IT is not involved in the development of corporate strategy

The absence of share meanings of key words and terms to establish the concept of business -IT strategy

The staff and employees do not understand that information technology has a much better potential than simply reducing costs

There is no accepted business strategy framework
Norton (2002); Luftman et al. (2002)

Luftman et al. (1999); Broadbent (2004);

Wagner et al. (2006)

Norton (2002); Chase (2002); Rathnam et al. (2005); Luftman et al. (1999)

Wagner et al. (2006); Banham (2002);

Rathnam et al. (2005); Luftman et al. (1999)

Broadbent (2004); Wagner et al. (2006);

Rathnam et al. (2005)

Luftman et al. (1999)

Majali and Dahlin (2010); Rathnam et al. (2005); Broadbent (2004)

Chase (2002); Banham (2002); Luftman et al. (1999)

Rathnam et al. (2005); Norton (2002)

Luftman et al. (1999); Majali and Dahlin (2010); Luftman et al. (2002); Norton (2002)

Rathnam et al. (2005); Norton (2002) 
data processing (Luftman et al. 1993). The gap started to occur when these two groups were involved in discussing problems and solutions using their exclusive terms and jargons.

Tallon and Kraemer (2002) warn that alignment gaps can still occur even though the company had already done the integration between IT strategies and business strategies, but because the business is conducted without the adequate articulation or clarification of the characteristics of the alignment, the alignment gap is not resolved. Research and discussions about factors that inhibit alignment and why an alignment gap persists (including Norton 2002; Banham 2002; Chase 2002; Broadbent 2004; Majali and Dahlin 2010) and the summary is shown in Table 4.

\section{IT Infrastructures and Characteristics of Flexibilities}

It can be inferred from Table 3 that the flexibility of IT infrastructures is the most important factor that encouraged alignment proposed by the researchers, therefore further discussion will focus on these factor. By adopting the definition developed by Byrd and Turner (2000), that IT infrastructures is a distributed component that consists of physical facilities such as hardware, software, communications technology, data, major applications, as well as components of personal skills and knowledge combined to develop IT services that are generally unique to the company, this study conducts a further exploration of the characteristics of the elements of flexibility, its functionalities, role toward alignment, and the considerations for its development.

Previous studies indicated that IT infrastructures flexibility is determined by four characteristics, namely connectivity, compatibility, modularity of IT infrastructures, and the knowledge and skills of IT staff. Connectivity links the various components of the company, thus allowing the information to be accessed from various locations. Compatibility creates the company's ability to harness together all forms of internal data and information, making it accessible to all parties regardless of their geographical location. Modularity means that the IT infrastructures is built on several components that interact with each other. Knowledge and skills of IT staff, reflects the knowledge and skills of staff who are able to utilize various forms of technology, are experienced in management and business, and are able to work cooperatively with everybody and from all departments of the company.

Based on these studies, a research question concerning how companies achieve and maintain alignment, and how IT infrastructures play a role in realizing alignment can be proposed. Implied in these questions are the why questions, leading to the following research question: How do characteristics of connectivity, compatibility, modularity of IT infrastructures, as well as knowledge and skills of IT staff contribute in achieving the company's strategic alignment.

\section{Research Methods and Data Analysis}

\section{Research Methods}

Observing the history of research in the field of information systems, Mingers (2002) noted that prior to the 1980 s quantitativepositivist paradigm dominated the articles that reported the results of the author's study. But after the 1980s, there emerged a group 
of studies based on different paradigms, some of which implement a qualitative-interpretive paradigm. The argument was based on the fact that the paradigm has a high sensitivity and appropriate for an in-depth examination of decision making toward the phenomena encountered in the study. In its application, it offers some research procedures which produce descriptive data in a form of words both written and oral from various sources observed. These data, according to Denzin and Lincoln (2000), should arrive from observation of a phenomenon "in a natural setting" with the intend to "make reasoning or interpretations of the phenomenon with the terminology that has meaning/purpose in accordance with what is desired by the perpetrator in the phenomenon."

From the stand point of epistemology, Chua (1986) developed an epistemology classification by mentioning three approaches, namely positivist, interpretive and critical approach, and all are valid to be adopted in qualitative research. In the interpretive research, researchers combined the results of their own subjective opinion, considering the reality as a social product that can not be understood independently of social actors (including researchers), who are also "builders" and who influenced the design of the subject of studies (Myers 1997).

A research method is a road map to get an answer that begins with the basic philosophical assumptions to the study design and data collection (Myers 1997). And there are several methods of research that can be used in interpretive research (Brechin and Sidell 2000) including case-study, action-research, and ethnography. This study was limited by space and time therefore an ethnography approach or method which requires researchers to assimilate into the firms studied for a relatively long time was impossible. This study was also not intended to give a treatment to the observed companies, therefore an actionresearch was not the right choice. Instead, the aim of this study is to develop an in-depth understanding of contemporary issue, based on "how" and "why" question, and conducted at the company's natural setting for exploring a phenomenon under study, therefore case study as a research design (Yin 2003) was appropriate to be adopted. Components of case study (Yin 2003) are presented in Table 6.

\section{Data Analysis}

There are various approaches to qualitative data analysis, with some being more suited to certain situations than others (Lacity and Janson 1994). Lacity and Janson (1994) cited some general approaches to text analysis with each being dependent on assumptions, to include the role of the researcher. Alternatives available to conduct an analysis of interpretive research data is hermeneutic and intentional analysis (Lacity and Janson 1994). Hermeneutic presumed that the interpreter had come from a different era with the author therefore is not appropriate for a contemporary text data. Instead, this study applied intentional procedures to analyze the data.

Intentional analysis is appropriate for understanding the intentions of participants observed during interviews, especially when researchers have some traits in common with the participants, such as age, live in the same culture, or speak the same language. The intentional analysis was done in four steps: (1) parsing, filtering, editing, and summarizing data, (2) interpretation and tabulation of data which made data easily combined/compared, (3) identification of themes for the development of interpretation, and (4) abstraction of the essence of the text. 
The results of the intentional phase then underwent some subsequence interpretation to arrive at the conclusion of the study. Parallel with intentional steps is an attempt to (1) determine the categories, definitions, and the level of abstraction of all policies, (2) formulate inductive research facts into cate-

Table 5. Case Study Components gories according to the definition of categories and abstraction, which is done step-bystep, and (3) classify the existing category or establish new categories (Lacity and Janson 1994). All of the analysis stages were performed in the context of "within-case analysis" and "cross-case analysis."

\begin{tabular}{ll}
\hline \multicolumn{1}{c}{ Components } & \multicolumn{1}{c}{ Descriptions } \\
\hline Context: & Information Systems \\
Research Questions & $\begin{array}{l}\text { How can strategic alignment be achieved. This answer will be an- } \\
\text { swered by examining how the various characteristics of IT infra- } \\
\text { structures flexibility components contribute to the strategic align- } \\
\text { ment. }\end{array}$
\end{tabular}

Boundary of the study Characteristics of IT infrastructures, the elements of the characteristics, descriptions about elements and various features as an alternative to develop each element. Based on literature review, these characteristics will include (but not limited to), connectivity, compatibility, modularity, knowledge and skills of IT staff.

Unit analysis

Strategic alignment (holistic)

Type of the case study Multi-case

Number of cases

Four cases: 1. PLN Kantor Distribusi Jawa Tengah and DIY, located at Semarang as a pilot (Disjateng).

2. PLN Kantor Distribusi Jawa Timur, Surabaya (Disjatim).

3. PT Indosat Tbk, Jakarta (Indosat).

4. PT Pertamina, Jakarta (Pertamina).

Case selection criterias: With the literal replication as a consideration, each case is choosen based on the following reasons:

1. Willing to be accessed with Strategic-Alignment tools of measurements

2. Implementing or in the proccess of developing IT Master Plan.

In order to achieve richness of data to be collected and analyzed, each case is chosen based on the following criterias:

1. First case: a company that is still struggling to consolidate and integrate its IT systems and applications. 
Table 5 (Continued)

\begin{tabular}{|c|c|}
\hline Components & Descriptions \\
\hline & $\begin{array}{l}\text { 2. Second case: a company that won the annual award of the best } \\
\text { IT implementor and in the middle of expanding its IT systems. } \\
\text { 3. Third case: a big company with communications as the main com- } \\
\text { modity. } \\
\text { 4. Fourth case: a big oil company }\end{array}$ \\
\hline Data analysis: & Intentional analysis \\
\hline $\begin{array}{l}\text { Interpretation of the } \\
\text { findings: }\end{array}$ & $\begin{array}{l}\text { Besides providing contextual information, a number of criterias for } \\
\text { IT infrastructures flexibility from previous studies also assisted the } \\
\text { interpretation of the findings }\end{array}$ \\
\hline $\begin{array}{l}\text { Data collection } \\
\text { strategies: }\end{array}$ & $\begin{array}{l}\text { Data collection was conducted by means of: } \\
\text { - Structured and semi-structured interview, documentations, } \\
\text { - Direct/indirect observations, physical artefact observation. }\end{array}$ \\
\hline
\end{tabular}

The result of the preliminary analysis indicates the fact that all cases achieved alignment by providing flexible IT infrastructure, and the decisions taken by the companies can be grouped into four categories that focus on four characteristics of IT infrastructures flexibility. However, further analysis showed some indications that a new category, called integration, can be derived from two characteristics namely connectivity and compatibility. Thus, after all the evidence was analyzed, the study revealed the existence of the four characteristics of a flexible IT infrastructure, that have been indicated by previous literature, namely connectivity, compatibility, modularity, and the knowledge and skills of IT staff. Furthermore, this study proposes an additional characteristic, namely the integration of IT infrastructure to enhance the property of IT infrastructures characteristics.

\section{Result Findings and Discussion}

The findings of this study can be illustrated in the form of a fishbone diagram (presented in Figure 3). As illustrated in Figure 3 , there are five main bones that represent the five components of characteristics of IT infrastructures flexibilities: connectivity, compatibility, modularity, integration, and the knowledge and skills of IT staff, and all together boils down to provide the characteristics of flexible IT infrastructures. The infrastructures then drain its potential to support alignment.

Each component is built by a number of capabilities that side-by-side will build the character of a flexible IT infrastructures. Connectivity is supported by the capabilities of linking all components, providing acces- 


\section{Figure 3. Flexible IT infrastructures and Strategic Alignment}

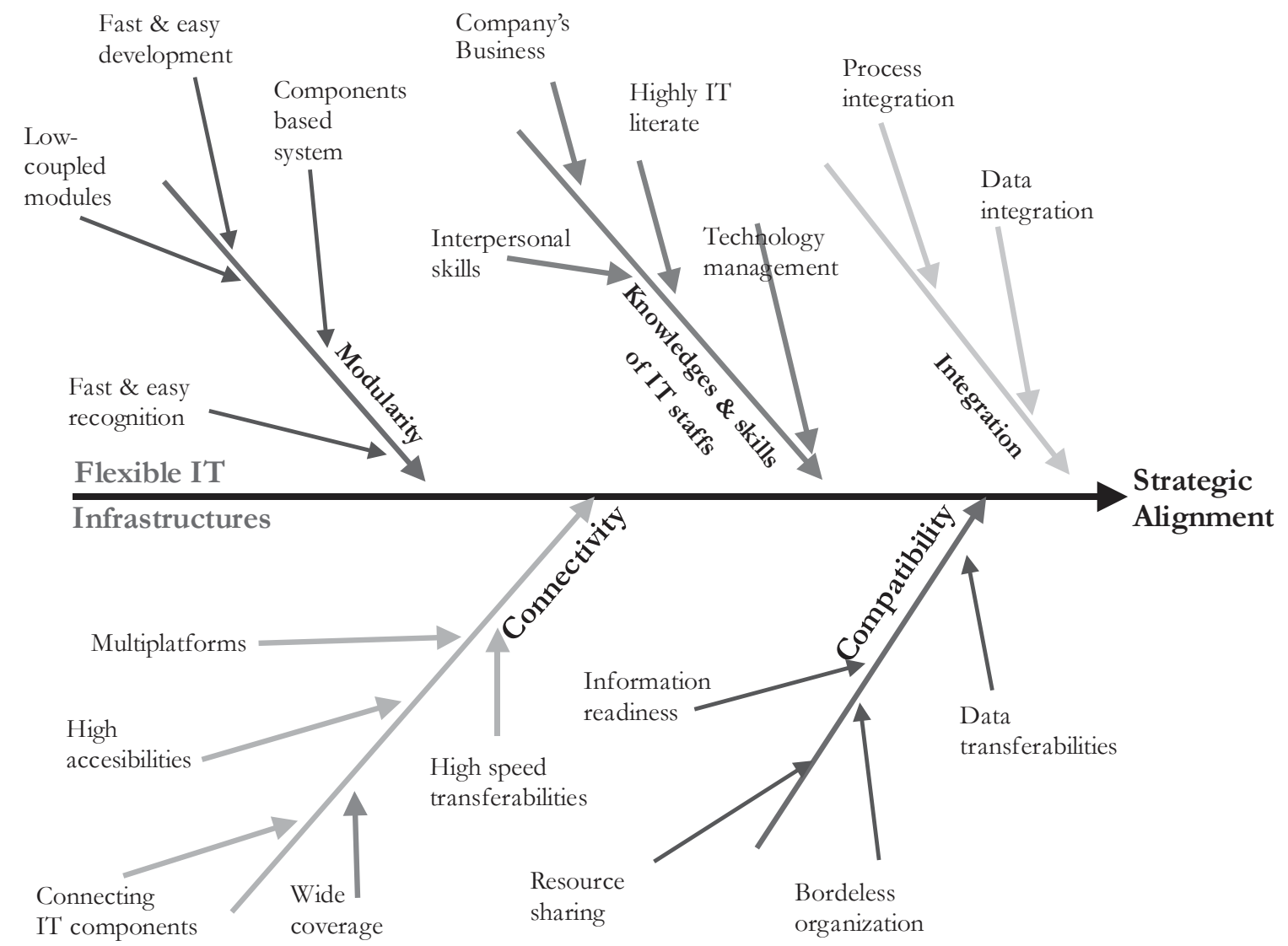

sibility, serving multiplatform, and distribute information with a wide range. Compatibility is supported by the capabilities of shared resources, provide ready-made information, expanding organizational boundaries, and transporting data. Modularity gives support in a form of the ability to easily and quickly constructed/reconfigured. Integration characteristic has the capabilities in a form of process integration and data integration. Furthermore, the IT staff contribution is in a form of knowledge and skills concerning information technology, technology management, business and interpersonal relationships.

As mentioned earlier, flexibility of IT infrastructures has a dominant share in realizing, improving, and maintaining alignment because alignment requires compatibility and harmonious relationship between business strategies and IT strategies. This means that when business strategies have to be altered by the demands of corporate environments, the IT strategies have the capabilities to be promptly compensated, a condition that will only happen if the IT strategies are supported by a flexible IT infrastructure.

The lessons learn from the case study are in line with statements expressed by Weill et al. (2002) as well as Chung et al. (2003) that IT strategies have the ability to change easily and quickly only when IT infrastructure is flexible, and that the flexibility of the IT infrastructure is one of the most important components of alignment due to a flexi- 
ble IT infrastructure, the implementation of the various types of applications in the enterprise can be built and modified quickly and easily.

Likewise Tallon and Kraemer (2003) in their article, drew two main conclusions from their observations, that a company with high flexibility IT infrastructure realized the sustainability of alignment, and the company can use the flexibility to achieve a higher degree of alignment.
As discussed earlier, there are five main components of IT infrastructures flexibility characteristics, with one of them, namely integration, are the findings of this study. The other four components are the connectivity, compatibility, modularity, knowledge and skills of IT staff. All components contribute to the flexibility of IT infrastructures in a holistic manner, which then drain its power to realize the strategic alignment. Table 6 presents characteristics of the flexibility IT in-

\section{Table 6. Flexibility Characteristics of IT components Infrastructures}

\section{Components Main Functions/Features}

(1)

(2)

\section{Effort to be Taken}

(3)

\begin{tabular}{|c|c|c|}
\hline Connectivity & $\begin{array}{l}\text { 1. Enable connection of all IT } \\
\text { components } \\
\text { 2. High accessabilities } \\
\text { 3. Wide coverage } \\
\text { 4. Multiplatform operations } \\
\text { 5. High speed information } \\
\text { transferabilities }\end{array}$ & $\begin{array}{l}\text { 1. Developing internet and } \\
\text { multiplatform architecture based IT } \\
\text { infrastructures } \\
\text { 2. Implementing web-based applica- } \\
\text { tion systems } \\
\text { 3. Developing centralized management } \\
\text { and maximizing standardization } \\
\text { 4. Consolidating server/storage }\end{array}$ \\
\hline Compatibility & $\begin{array}{l}\text { 1. Enable provision of resources } \\
\text { sharing } \\
\text { 2. Provide borderless organization } \\
\text { 3. Provide readyness information } \\
\text { 4. Enable transformation of data }\end{array}$ & $\begin{array}{l}\text { 1. Adopting middleware technologies } \\
\text { (XML, DDP, and GML for } \\
\text { geospacial data) } \\
\text { 2. Implementing standardized-XML } \\
\text { and web-based EDI } \\
\text { 3. Encouraging open-standard } \\
\text { 4. Encouraging consolidation } \\
\text { 5. Implementing real-time, online, } \\
\text { multi-user database }\end{array}$ \\
\hline Modularity & $\begin{array}{l}\text { 1. Components based IT infra- } \\
\text { structures } \\
\text { 2. Low-coupled interelation } \\
\text { between components } \\
\text { 3. Quick and easy to be developed } \\
\text { 4. Quick and easy to be } \\
\text { reconfigured }\end{array}$ & $\begin{array}{l}\text { 1. Implementing software engineering } \\
\text { concept such as formal methods, } \\
\text { object-oriented, and software } \\
\text { configuration management to } \\
\text { develop and maintain software } \\
\text { applications } \\
\text {.2. Developing client-server database } \\
\text { architectures } \\
\text { 3. Adopting data-independency } \\
\text { concepts }\end{array}$ \\
\hline
\end{tabular}


Table 6 (Continued)

\section{Components}

(1)

\section{Main Functions/Features}

(2)
Effort to be Taken

(3)
Integration

1. Enable data integration

2. Enable process integration
1. Developing high accessability and wide range IT infrastructures networks to provide data/audio as well as multi-media communication channel

2. Implementing real-time, online, and web-based application systems supporting with centralized and standardized database architecture

Knowledges and skills

1. Provided with knowledges and skills to manage IT as a system

2. Provided with interpersonal knowledges and skills

3. Provided with knowledges and skills to insight company's business

4. Highly IT literat
1. Providing and encouraging staff to conduct self-exploring

2. Encouraging staff to pursue higher education

3. Creating interdepartemental and sustainable training projects

4. Encouraging staffs involvement in an IT decision making process frastructures components (shown in column 1), functions/features as the principal components that emerged from the data collection process are shown in colomn 2. Whereas decisions made by the companies to achieve the presence of the function/characteristics are presented in column 3 (Table 6).

\section{Conclusion and Implications}

This study aimed to build an in-depth understanding of strategic alignment, an important organizational aspect in the context of Information Systems field of study, by applying the qualitative-interpretive case study approach. Data was analyzed by adopting texts analysis by means of intentional analysis. Besides providing contextual information, a number of criterias for IT infra- structures flexibility from previous studies also assisted the interpretation of the findings.

\section{Conclusion}

The main conclusion of this study is that irrespective of the company's perspectives of alignment and their business typicality, all cases have the same indication of policy to achieve alignment, which is to provide flexible IT infrastructures. Perspective of the case is "a fusion of infrastructures" for Disjateng, "competitive potential" for Disjatim and Indosat, and "technological potential" for Pertamina. Disjatim and Disjateng are companies that provide services in the fields of electrical energy, while Indosat and Pertamina are in the field of communications and oil respectively. In terms of IT utilization, 
Disjateng are in the process of consolidation and integration work, while three other cases already at the stage of expansion.

IT infrastructures flexibilites developed by each case were constructed by five components characteristics of flexibility, and the results of this exploratory research is also lead to conclusion that strategic alignment requires the synergy of all these characteristics simultaneously. These are conditions where a company provides IT infrastructure with some crucial capabilities such as easily expanded or reconfigured according to the changing of business strategies quickly and effortlessly. Analyzing the case indicated that the characteristics of IT infrastructures flexibility that could encourage companies in developing and maintaining alignment have the following descriptions:

1. Connectivity. Connectivity of IT infrastructures is the infrastructures capability to meet the demand of connections between staffs, functional areas, or applications, covering both inside and outside the company, and that each entity can make some interactions with each other. As a result, cross-communi-cation can be provided and that user can utilize and share information regardless of organizational boundaries. These conditions allow responses to changes from within and outside company be obtained rapidly.

2. Compatibility. Compatibility of IT infrastructures is the ability of company to share all components of IT infrastructures by all entities within the company without having to own the technology (platforms and/or equipment access) that are exactly equal to the one operate by the company. Compatibility creates more empowered employees, and provides all data and information used as a basis for deci- sion making be prepared quickly and accurately.

3. Modularity. Modularity is the ability of the IT infrastructures components to be developed or modified into new forms or configurations in order to meet requirements initiated by the business. IT infrastructures with a high level of modularity is the IT infrastructures that requires lesser time and efforts to respond to any changes in business strategies.

4. Knowledge and skills of IT staff. Knowledge and skills that contribute to the flexible IT infrastructures is related to the ability of the staff to work cooperatively in a group of cross-sections, using various technologies thereby expanding its organizational boundaries, and to help companies in dealing with changes, whether from internal or external companies.

5. Integration. Flexible IT infrastructure capable of integrating important data and processes in supporting the availability of information that is ready to be exploited in order to speed up decision making and transfer of information from one location to another. Integration in this study can be viewed as the synergy of connectivity and compatibility capabilities.

\section{Research Weakness and Limitations}

As with all academic work, this study has limitations which can be avoided in further studies. First of all, this study didn't show the process that brought the case to the policymaking related to building and maintaining company's flexible IT infrastructures. Second, the study didn't elaborate the acquisition of IT infrastructures flexibility to support their involvement in achieving strategic alignment. Another limitation has something to do with 
the method choosen to conduct the study. This study adopted a case study on four companies only. This short list of involved companies may not reflect the actual situation for other Indonesian companies. Four companies were only chosen due to the time and access limitations. However, the chosen companies represent three different industries. Lastly, although it can be considered to be a specific limitation, when the results of research that adopts a case study, it is necessary to be prudent if one intends apply it to other companies with different conditions and typicality.

\section{Contributions of the Study}

This study identifies flexible IT infrastructure as dominant factors that contribute to achieving strategic alignment. In addition, this study also described the characteristics of five components of IT flexible infrastructures including integration -a characteristic proposed by this research. Integration can be exploited in the future study as research construct in a sense that it could eliminate another characteristics (eg, connectivity and compatibility).

The analysis indicates that companies with flexible IT infrastructures are likely to have centralized IT decision-making in nature. Centralzation was imposed both for decisions related to IT strategy and infrastructure's policies. Based on the implications of strategic alignment to the company (such as improving performance and competitive advantage), the world required more extensive research in the areas of strategic alignment and the conditions that support or inhibit the alignment. Some research topics that can be further explored, among other things are:
1. Theory testing. It is worthwhile to examine the relationship between strategic alignment with the implementation of IT applications and infrastructures flexibility. How could the implementation of the application and the five components of IT infrastructures flexibility contributes to strategic alignment be tested?

2. Theory modification. Technology changes very quickly, and it is possible for one of the IT infrastructures components or characteristics that were explored in this study had a different emphasis in the future. Such research needs to be done because it allows the emergence of a new characteristic components of IT infrastructures flexibility or new policy implications that lead to the management of IT infrastructures in more effective/efficient and in creating and maintaining strategic alignment.

3. Extending the case. Another area of research that can be selected by the researchers to deepen the understanding of strategic alignment is to determine different components of the case study and examine whether there is a common factor in the case being studied. Furthermore, the selection of cases can also be determined based on the same industry, similar government agencies, or companies with a category of small/medium size to observe how companies, organizations, or institutions pursuing strategic alignment.

4. Alignment gap identification. Alignment gaps can be the next alternative of research topics that need to be focused on in order to gain an understanding of strategic alignment. The prior studies had indicated the existence of alignment gaps and tried 
to resolve the problems. However, due to the dynamic progress in terms of technological and environmental conditions, it is necessary to identify whether these observations are still appropriate.

\section{Management Implications}

Managers can utilize the research results to develop a more comprehensive action plan to achieve or enhance strategic alignment, and also to translate the alignment in order to increase the role of IT in business performance. One alternative is, that companies need to position their strategic IT functions within the organizational structure of the company, meaning that IT executives have a direct access to business executives. With this position it is expected that any IT acquisition and procurement of new technology is always done on purpose to give support to the business strategy.

The study also placed alignment as a topic that has the context of Information Systems, a multidimensional science that involves both social and technical dimensions. Therefore, executives from both IT and business need to consider the managerial and organizational dimensions of the wider information systems to understand the current issues on IT investment.

\section{Macro Policy Implications}

The ability of the IT department and the business department to collaborate must be at the forefront in terms of strategic vision of IT and the understanding of technical issues that can lead to the development of a simple but efficient architectural design. An architect plays a very important role in determining whether an IT strategy can easily and quickly respond to dynamic changes both coming from inside or from outside the company. This study expands this idea by showing how flexible IT infrastructures capabilities achieve alignment. Therefore, from the macro side, policy makers (in this case the government) can use this research to motivate the provision of communication infrastructure (internet and telecommunications) that is cheap and that can be safely accessed by the public. Likewise, both technical and procedural standardization for business through the means of communication should be developed to foster a safe and positive atmosphere for the public in conducting electronic transactions. Last but not least, the company should establish rules and regulations that are able to create a stable market environment, and IT-oriented education that leads to the improvement of IT.

\section{Reference}

Al Majali, D., and Z. Dahlin. 2001. Diagnosing the gap in it - business strategic alignment: A qualitative analysis among public shareholding firms in Jordan. International Journal of Electronic Business Management 8 (4): 263-271.

Andersen, T. J. 2001. Information technology, strategic decision making approaches and organizational performance in different industrial setting. Journal of Strategic Information Systems 10 (2): 101-119.

Banham, R., 2000. Better budgets. Journal of Accountancy 189 (2): 37-40. 
Bhatt, G. D., and V. Grover. 2005. Types of information technology capabilities and their role in competitive advantage: An empirical study. Journal of Management Information Systems 22 (2): 253-277.

Bond, F. W., S. C. Hayes and D. Barnes-Holmes. 2006. Psychological flexibility, ACT, and organizational behavior. Journal of Organizational Behavior Management 26 (1): 25-54.

Brechin, A., and M. Sidell. 2000. Ways of knowing. In: R Gomm, and C. Davies (eds.), Using Evidence in Health and Social Care: 3-25. London: Sage and The Open University.

Broadbent, M. 2004. Where's the strategy?" CIO Insight 46: 35-36.

Broadbent, M., and P. 1977. Weill. Management by Maxim: How business and information technology management can create information technology infrastructure. Sloan Management Review 38 (3): 77 92.

Bütschi, G., and B. Steyn. 2008. Achieving strategic alignment in public relations through the development of an research based software engineering. Proceedings of the $11^{\text {th }}$ Annual Public Relations Research Conference (March). Miami, FL.

Byrd, T. A., and D. E. Turner. 2001. An exploratory examination of the relationship between flexible IT infrastructure and competitive advantage. Information and Management 39 (1): 41-52.

Byrd, T. A., and D. E. Turner. 2000. Measuring the flexibility of information technology infrastructure: Exploratory analysis of a construct. Journal of Management Information Systems 17 (1): 167- 208.

Chan, Y. E., and B. H. Reich. 2007. IT alignment: An annotated bibliography. Journal of Information Tecbnology 22 (4): 316-396.

Chan, Y. E., and S. Huff. 1993. Strategic information systems alignment. Business Quarterly 58 (1): 51-56.

Chan, Y. E., S. L. Huff, D. W. Barclay and D. G. Copeland. 1997. Business strategic orientation systems, strategic orientation and strategic alignment. Informastion Systems Research 8 (2): 125 - 150.

Chanopas, A, D. Krairit and D. B. Khang. 2006. Managing information technology infrastructure: A new flexibility framework. Management Research News 29: 632. - 651.

Chase, C. 2002. Turning knowledge into action at Heinekin USA. Knowledge Management Review 5 (2): 22-25.

Chen, Y., and H. Huang. 2010. Performance implications and strategic alignment of knowledge management strategy and strategic information technology management. Proceedings of the The $11^{\text {th }}$ Asia Pacific Industrial Engineering and Management Systems Conference.

Chua, W. F. 1986. Radical developments in accounting thought. The Accounting Review 61 (4): 601-632.

Chung, S. H., R. K. Rainer, and B. R. Lewis. 2003. The impact of IT infrastructure flexibility on strategic alignment and applications implementation. Communication of the Association for Information Systems 11: $191-206$.

Cragg, P. B., M. King, and H. Hussin. 2002. IT alignment and firm performance in small manufacturing firms. Journal of Strategic Information Systems 11 (2): 109-132.

Croteau, A. M., and F. Bergeron. 2001. An information technology trilogy: Business strategy, technologycal deployment and organizational performance. Journal of Strategic Information Systems 10 (2): 77 - 99.

Das S. R., S. A. Zahra, and M. E. Warkentin. 1991. Integrating the content and process of strategic MIS planning with competitive strategy. Decision Sciences 22: 953 - 984.

Denzin, N. K., and Y. S. Lincoln. 200. Introduction: the discipline and practice of qualitative research. In N. K. Denzin and Y. Lincoln (Eds.), Handbook of Qualitative Research. Thousand Oaks, CA: Sage. 
Duncan, N. 1995. Capturing flexibility of information technology infrastructure: A study of resource characteristics and their measure. Journal of Management Information Systems 12 (2): 37-57.

Elhari, K., and B. Bounabat. 2011. Platform for assessing strategic alignment using enterprise architecture: Application to e-government process assessment. International Journal of Computer Science Issues 8 (1): 265-274.

Gebauer, J., and F. Schober. 2005. Information system flexibility and the cost efficiency of business processes. Journal of the Association for Information Systems. 1-34.

Henderson J. C., and N. Venkatraman. 1993. Strategic alignment: Leveraging IT for transforming organization. IBM System Journal 32 (1): 4 - 16.

Henderson, J. C., and N. Venkatraman. 1992. Strategic alignment: a model for organizational transformation through information technology. In Kochan, T. A. and M. Useem (Eds.), Transforming Organizations. Oxford University Press, Oxford and New York.

Hussain, H., M. King, and P. Cragg. 2002. IT alignments in small firms. European Journal of Information Systems 11: 108-127.

Jahng, J., and K. Ramamurty. 1998. Influence of IT architectural strategy and business strategy alignment on competitive advantage. A Proposed Researh Framework. http:// www/ isworld.org/ ais.ac.98/ proceedings/ track11/ jahng.pdf, (access 28 Oktober 2001).

Johnson, A., and A. Lederer. 2010. CEO/CIO Mutual understanding, strategic alignment, and the contribution of IS to the organization. Information and Management 47 (3): 138-149.

Kanelis, P., and R. J. Paul. 2005. User behaving badly; phenomena and paradoxes from an investigation into information systems misfit. Journal of Organizational and End user Computing 17 (12): 64-91. IDEA Group Publishing.

Kearns, G. S. and A. L. Lederer. 1997. Alignment of information systems plans with business plans: The impact on competitive advantage. Proceedings of the Third Americas Confererence on Information Systems. Indianapolis, Indiana.

Kearns, G. S., and A. L. Lederer. 2001. Strategic IT alignment, a model for competitive advantage. Proceedings of the Twenty-second International Conference on Information Systems. New Orleans, LA.

Kim, K. 2003. A socio-intellectual framework empirically testing the factors affecting the alignment between business and IS strategies. American Management of Computer Information Systems: 2795-2800.

Knoll, K., and S. L. Jarvenpaa. 1995. Learning to work in distributed global teams. Proceedings of the Twenty-Eighth Annual Hawaii International Conference on Systems Sciences.

Lacity, M., and M. A. Jansen. 1994. Understanding qualitative data: A framework of text analysis methods. Journal of Management Information Systems 11: 137-166.

Lederer, A., and A. Mendelow. 1989. The coordination of information systems plans with business plans. Journal of Management Information Systems 6 (2) (Fall): 5-19.

Luftman, J. N. 1996. Applying the strategic alignment model. In J. Luftman (Ed.), Competing in the Information Age: Strategic Alignment in Practise: 43-69. NY: Oxford University Press.

Luftman, J. N., and T. Brier. 1999. Achieving and sustaining business IT alignment. California Management Review 42 (1): 109-122.

Luftman, J. N. 2000. Addessing business -information technology alignment maturity. Communication of AIS 4 (14): 1-50. 
Luftman, J. N., R. Papp and T. Brier. 2002. Enablers and inhibitors of business-IT alignment. ABInsight. Luftman, J. N. 2003. Measure your business-IT alignment. Optimize: Business Execution for CIOs Magazine 26.

Luftman, J. N., R. Kempaiah, and E. Nash. 2005. Key issues for IT executives. MIS Quarterly Executive 5 (2): 81-101.

Luftman, J. N. and T. Ben-Zvi. 2010. Key Issues for IT executives (2009): Difficult economy's impact on IT. MIS Quarterly Executive 9: 1-20.

McKaway, M., L. Rusu, and N. Ahmed. 2009. Business and IT Alignment: An Evaluation of Strategic Alignment Models. www.springerlink.com/index/q41362q870417153.pdf (acces Januari 2011).

Mingers, J. 2002. Realizing information systems: Critical realism as an underpinning philosophy for information systems. Twenty-Third Internat. Conf. Information Systems: 295-303. Barcelona, Spain.

Myers, M. D. 1997. Qualitatif research in information systems. MIS Quarterly 21 (2) (June): 241-242.

Ness, L. R. 2005. Assessing the relationships among information technology flexibility, strategic alignment, and information technology effectiveness. Ph.D. Dissertation. Northcentral University, United States - Arizona. Retrieved May 27, 2009, from Dissertations \& Theses: Full Text database. (Publication No. AAT 3178531).

Norton, D. 2002. Becoming a strategic partner. Keynote Address at the Human Resource Masters Symposium 2002. Sponsored by Linkage and HR.com, Palm Springs, CA.

Overby, E., A. 2006. Bharadwaj and V. Sambamurth. 2006. Enterprise agility and the enabling role of information technology. European Journal of Information Systems, 2006: 120-131.

Pant, S., and C. HSU. 1999. An integrated framework for strategic information systems planning and development. Information Resources Management Journal 12 (1): 15-25.

Papp, R. 1999. Business-IT alignment: productivity paradox. Industrial Management \& Data Systems 99 (8): 367-373.

Papp, R. 2001. Strategic Information Technology: Opportunities for Competitive Advantage. Hershey PA: IDEA Group Publishing.

Porter, M. E., and V. E. Millar. 1985. How information gives you competitive advantages. Harvard Business Review (July-Augustus): 149 - 160.

Rathnam, R. G., J. Johnsen, and H. J. Wen. 2005. Alignment of business strategy and IT strategy: A case study of Fortune 50 Financial Service Company. Journal of Information Systems: 1 - 9.

Reich, B. H., and I. Benbasat. 2000. Factors that influence the social dimension of alignment between business and information technology objectives. MIS Quarterly 24 (1): 81 - 114.

Reich, B. H., and I. Benbasat. 1996. Measuring the linkage between business and information technology objectives. MIS Quarterly 20 (1): 55 - 81.

Rockart, J. 1979. Chief executives define their own information needs. Harvard Business Review (March/ April): 81-92.

Sabherwal, R., and Y. E. Chan. 2001. Alignment between business and information strategies: A case study of prospectors, analyzers, and defenders. Information Systems Research 12 (1): 11 - 33.

Sabherwal, R., and P. Kirs. 1994. The alignment between organizational critical success factor and information technology capability in academic institutions. Decision Sciences 25 (2): 301 - 330. 
Sambamurty, V. 2000. Business strategy in hypercompetitive environments rethinking the logic of IT differentiation. In Zmud, R.W. E (Edt.), Framing the Domain of IT Management: 245-261. Pinnaflex Educational Resources, Cinccinati, $\mathrm{OH}$.

Sambamurty, V., and R. W. Zmud. 1999. Arrangements for information technology covernance: A theory of multiple contngency. MIS Quarterly 23 (2): 261 - 290.

Smith, G., K. Watson, W. Baker, and J. Pokorski. 2007. A critical balance: Collaboration and security in the IT-enabled supply chain. International Journal of Production Research (June).

Tallon, P. 2009. How IT infrastructure flexibility shapes strategic alignment: A case study investigation with implications for strategic IS planning. In W.R. King (Edt.), Planning for Information Systems. M. E.: Sharpe Publishers.

Tallon, P., K. L. Kraemer, and V. Gurbaxani. 2000. Executives' perceptions of the business value of information technology: A process-oriented approach. Journal of Management Information Systems 16: 145-173.

Van Der Zee, J. T. M., and B. De Jong. 1999. Alignment is not enough: Integrating business and information technology management with the balanced business scorecard. Journal of Management Information Systems 16 (2): 137 - 156.

Wagner, H. T., D. Beimborn, J. Franke, and T. Weitzel. 2006. IT business alignment and IT usage in operational processess: A retail banking case. Proceedings of the $39^{\text {th }}$ Hawaii International Conference on System Sciences. 1-9.

Weill, P., M. Subramani, and M. Broadbent. 2002. Building IT infrastructure for strategic agility. Sloan Management Review 44 (1): 57-65.

Woolfe, R. 1993. The path to strategic alignment. Information Strategy 9 (2): 13-23.

Xia, W., and W. R. King. 2002. Determinants of organizational IT infrastructure capabilities: An empirical study. Working Paper (March). MIS Research Center, University of Minnesota, Helsinki School of Economics, P.O. Box 1210, 00101 Helsinki, Finland, mari.nyrhinen@hse.fi.

Yin, R. K. 2003. Case Study Research, Design and Methods ( $3^{\text {nd }}$ eds.). Thousand Oaks CA: Sage Publications. 